\title{
Stimulation of progesterone production in bovine luteal cells by co-incubation with bovine blastocyst-stage embryos or trophoblastic vesicles
}

\author{
J. K. Thibodeaux*, J. R. Broussard, R. A. Godke and W. Hansel ${ }^{\dagger}$ \\ Department of Animal Science, LAES, LSU Agricultural Center, Louisiana State University, Baton Rouge, \\ LA 70803, USA
}

\begin{abstract}
A study was conducted to determine whether bovine blastocyst-stage embryos and trophoblastic vesicles stimulate the production of progesterone in bovine luteal cells during incubation in vitro. The effects of co-incubation of these embryos and vesicles with uterine endometrial tissue on progesterone production was also investigated. Bovine small and large luteal cells were obtained on day 12 of the oestrous cycle, dispersed by unit gravity sedimentation and recombined to provide preparations free of accessory cells. Blastocyststage embryos were obtained on day 7 and trophoblastic vesicles were obtained from bovine embryos on day 12 . A uterine endometrial tissue sample was obtained from the same cow from which the corpus luteum was taken. Treatment groups were arranged in 24-well plates as follows: luteal cells alone; luteal cells and one trophoblastic vesicle; luteal cells and one blastocyst embryo; luteal cells and a $10 \mathrm{mg}$ uterine endometrial sample; luteal cells, one trophoblastic vesicle and a uterine endometrial sample; and luteal cells, one blastocyst embryo and a uterine endometrial sample. All treatment groups were incubated (at $37^{\circ} \mathrm{C}$ under $5 \% \mathrm{CO}_{2}$ ) in Ham's F-12 medium supplemented with antibiotics ( $100 \mu \mathrm{g}$ penicillin $\mathrm{ml}^{-1}$ and $100 \mathrm{U}$ streptomycin $\mathrm{ml}^{-1}$, L-glutamine $\left(0.29 \mathrm{mg} \mathrm{ml}^{-1}\right)$, insulin $\left(5 \mu \mathrm{g} \mathrm{ml}^{-1}\right)$, transferrin $\left(5 \mu \mathrm{g} \mathrm{ml}^{-1}\right)$ and selenium $\left(5 \mathrm{ng} \mathrm{ml}^{-1}\right)$ for $12 \mathrm{~h}$. Samples of the medium were harvested $10 \mathrm{~min}$ (basal concentration) and 2, 6 and $12 \mathrm{~h}$ after incubation to determine the concentrations of progesterone and prostaglandin. The major findings of this study were that both trophoblastic vesicles and blastocyst-stage embryos stimulated progesterone production during the $12 \mathrm{~h}$ incubation. In addition, the uterine endometrial sample partially inhibited the stimulatory actions of trophoblastic vesicles and blastocyst embryos after $12 \mathrm{~h}$ of incubation.
\end{abstract}

\section{Introduction}

Significant increases in progesterone concentrations in plasma (Lukaszewska and Hansel, 1980) and milk (Lamming et al., 1989) in pregnant compared with nonpregnant cattle have been found as early as day 8 after oestrus. This finding indicates that some form of luteotrophic activity is produced by the bovine conceptus before day 16, the day most often cited as the day of maternal recognition of pregnancy (Betteridge et al., 1980; Northey and French, 1980). Homogenates and aqueous extracts of homogenates of bovine conceptuses at day 13-18 stimulate progesterone synthesis when added to dispersed bovine luteal cells (Beal et al., 1981). The active compound(s) is a lipid-soluble, heat-labile luteotrophin(s) of $<10 \mathrm{kDa}$ (Hickey and Hansel, 1987). In addition, intra-

*Present address: Tulsa Center for Fertility and Women's Health, Tulsa, OK 74104, USA.

${ }^{\dagger}$ Reprint requests.

Received 13 December 1993. uterine infusion of 'conceptus secretory proteins' from cultures of day 17-18 conceptuses between day 15 and day 17 after oestrus extends the duration of the oestrous cycle (Thatcher et al., 1985).

Specific genes encoding products that exhibit luteotrophic or antiluteolytic properties have been detected in early-stage bovine embryos. Platelet-derived growth factor stimulates progesterone production in luteal cells (Battista et al., 1989) and the gene and receptor for this ligand are present in all developmental stages of bovine embryos before they hatch from the zona pellucida (Watson et al., 1992). In addition, mRNA for bovine trophoblast protein-1 (bTP-1) was detected in blastocyst-stage bovine embryos (Hernandez-Ledezma et al., 1992); intrauterine infusion of this protein into cyclic cows between day 14 and day 17 extends the lifespan of the corpus luteum and decreases the concentration of $\mathrm{PGF}_{2 \alpha}$ (Helmer et al., 1989a). Endometrial explants exhibit a decrease in $\mathrm{PGF}_{2 \alpha}$ concentration and an increase in the secretion of PGE in response to bTP-1 (Helmer et al., 1989b). 
Several factors secreted by bovine embryos, such as plateletactivating factor (Stock and Hansel, 1992), steroids and prostanoids (Shemesh et al., 1979; Shemesh et al., 1984; Hwang et al., 1988; Lewis, 1989; Wilson et al., 1992) and bTP-1 (Thatcher et al., 1989; Hernandez-Ledezma et al., 1992) before day 16 may be involved in the maternal recognition of pregnancy. However, many of these products may exert their effects through localized interactions with the uterine endometrium.

This experiment was designed to determine whether blastocyst-stage embryos before they hatch from the zona pellucida, or trophoblastic vesicles obtained from bovine conceptuses at day 12 exhibit luteotrophic activity alone or in combination with uterine endometrial tissue when added to mixed populations of dispersed small and large bovine luteal cells.

\section{Materials and Methods}

\section{Superovulation}

A group of normally cyclic mixed breed beef cows was injected i.m. once a day with FSH (FSH-P; Schering, Kenilworth, NJ), beginning on day 8-12 of the oestrous cycle (oestrus $=$ day 0 ) for 5 consecutive days. A single injection of $\mathrm{PGF}_{2 \alpha}$ (Upjohn, Midland, MI) was administered on the evening of the fourth FSH-P treatment. Animals were artificially inseminated and mated with a fertile bull $12 \mathrm{~h}$ and $24 \mathrm{~h}$ after the onset of oestrus.

\section{Embryo collection and culture}

Twelve days after the induction of the superovulatory oestrus, the uterus of each cow was flushed nonsurgically with Dulbecco's PBS (D-PBS: Gibco Laboratories, Grand Island, NY), containing $1 \%$ calf serum (Gibco) and antibiotics (100 $\mu \mathrm{g}$ penicillin $\mathrm{ml}^{-1}$ and $100 \mathrm{U}$ streptomycin $\mathrm{ml}^{-1} ;$ Gibco). The conceptuses were removed from the flushing medium and washed in fresh D-PBS plus 10\% fetal bovine serum (FBS: Gibco) and antibiotics in sterile Petri dishes.

Conceptuses were washed through several drops of fresh medium and dissected to prepare trophoblastic vesicles according to procedures described by Pool et al. (1988). After dissection, tissue segments were washed several times in Ham's F-12 medium (Sigma Chemical Co., St Louis, MO) containing $10 \% \mathrm{FBS}$ and antibiotics, and incubated for approximately $24 \mathrm{~h}$ at $39^{\circ} \mathrm{C}$ under $5 \% \mathrm{CO}_{2}$ in humidified air to allow the conceptus tissue to re-expand.

Embryos at the morula and blastocyst stages were nonsurgically recovered from donor animals at a commercial embryo transplant unit, and frozen in liquid nitrogen. Embryos were thawed and co-cultured for approximately $24-48 \mathrm{~h}$ in vitro on oviductal epithelial cells as described by Thibodeaux et al. (1992, 1993) to obtain embryos at the blastocyst or expanded blastocyst stage for the experimental protocol. Embryos were initially cultured in tissue culture medium-199 (TCM-199; Gibco) containing $10 \% \mathrm{FBS}$ and antibiotics at $39^{\circ} \mathrm{C}$ under $5 \% \mathrm{CO}_{2}$ in humidified air. Immediately before allocation to treatment groups, blastocysts were washed several times in Ham's F-12 medium without serum.

\section{Luteal cell preparations}

Corpora lutea $(n=6)$ were enucleated from normal cyclic mixed breed beef and Holstein cows under epidural anaesthesia on day 10 of the oestrous cycle (oestrus = day 0 ) through a small incision in the anterior vagina, and placed in chilled $\left(4^{\circ} \mathrm{C}\right)$ TCM-199 containing antibiotics. Luteal tissue was dissociated using $2000 \mathrm{U}$ of collagenase $\mathrm{g}^{-1}$ of tissue (Worthington Biochemicals, Freehold, NJ) in TCM-199 at $34^{\circ} \mathrm{C}$ by the procedure described by Alila et al. (1988a). The cells were filtered through a silkscreen (pore diameter of $150 \mu \mathrm{m}$ ) and monofilament mesh ( $44 \mu \mathrm{m}$ in diameter) and separated by unit gravity sedimentation (Koos and Hansel, 1981). After unit gravity sedimentation, small and large luteal cell fractions were pooled to obtain mixed luteal cell preparations nearly free of accessory cells. The mean ( \pm SEM) viability of luteal cells after unit gravity sedimentation, as estimated by trypan blue dye exclusion, was $87.2 \pm 1.5 \%$ ( $n=6$ corpora lutea).

\section{Endometrial tissue}

A portion of uterine endometrial tissue was harvested from the same experimental animal that served as the corpus luteum donor. The tissue sample was harvested from the uterine horn ipsilateral to the corpus luteum using a uterine biopsy tool (Pilling Corporation, Fort Washington, PA). The recovered tissue was immediately placed on ice in TCM-199 containing antibiotics and transported to the laboratory.

After several washings in fresh medium, the uterine tissue sample was blotted with sterile gauze and cut into small segments that weighed approximately $10 \mathrm{mg}$ each. Each $10 \mathrm{mg}$ tissue segment was washed and placed into individual wells of a 24-well tissue culture plate (Corning Glass Works, Corning, $\mathrm{NY}$ ) containing $500 \mu \mathrm{l}$ of cell culture medium, and incubated for $2-3 \mathrm{~h}$ at $37^{\circ} \mathrm{C}$ under $5 \% \mathrm{CO}_{2}$ in humidified air before the experiment began. The cell culture medium consisted of Ham's F-12 medium supplemented with antibiotics, L-glutamine $\left(0.29 \mathrm{mg} \mathrm{ml}^{-1}\right)$, insulin $\left(5 \mu \mathrm{g} \mathrm{ml}^{-1}\right)$, transferrin $\left(5 \mu \mathrm{g} \mathrm{ml}^{-1}\right)$ and selenium (5 $\mathrm{ng} \mathrm{ml}^{-1}$ ). Immediately before the experimental protocol began, the culture medium was removed from each well and the endometrial tissue was washed twice with fresh cell culture medium.

\section{Incubation conditions}

Treatment groups were arranged in individual wells of a 24-well tissue culture plate as follows: luteal cells alone; one trophoblastic vesicle alone; one blastocyst-stage embryo alone; one $10 \mathrm{mg}$ sample of uterine endometrial tissue alone; luteal cells and one trophoblastic vesicle; luteal cells and one blastocyst-stage embryo; luteal cells and a $10 \mathrm{mg}$ sample of uterine endometrial tissue; luteal cells, one trophoblastic vesicle and a $10 \mathrm{mg}$ uterine endometrial sample; and luteal cells, one blastocyst-stage embryo and a $10 \mathrm{mg}$ uterine endometrial sample. Luteal cells were added to each well at a concentration of 250000 viable cells per well and the total volume of medium in each well was $500 \mu \mathrm{l}$. There were two to four replicates for each treatment for each corpus luteum.

All treatment wells were incubated at $37^{\circ} \mathrm{C}$ in an atmosphere of $5 \% \mathrm{CO}_{2}$ in humidified air for $12 \mathrm{~h}$. A sample of medium 
$(100 \mu \mathrm{l})$ from each treatment was withdrawn $10 \mathrm{~min}$ (basal concentration), and 2 and $6 \mathrm{~h}$ after the treatment began, and was stored at $-20^{\circ} \mathrm{C}$ for progesterone assay. Equal volumes of fresh medium were replaced following sample collection. After $12 \mathrm{~h}$ of treatment, the culture medium (approximately $500 \mu \mathrm{l}$ ) for each treatment group was removed and stored at $-20^{\circ} \mathrm{C}$ for progesterone assay. In addition, media samples harvested from the uterine endometrium culture treatment were assayed for $\mathrm{PGF}_{2 \alpha}, \mathrm{PGE}_{2}$ and 6-keto $\mathrm{PGF}_{1 \alpha}$.

\section{Progesterone determination}

The concentration of progesterone in the culture medium was measured by enzymeimmunoassay procedures that have been reported and validated by Del Vecchio et al. (1993). The sensitivity of the assay was $1.56 \mathrm{pg}$ per well and allowed for the measurement of $0.03125 \mathrm{ng} \mathrm{ml}^{-1}$; the intra-assay and interassay coefficients of variation were 6.3 and $13.2 \%$, respectively.

\section{Prostaglandin determination}

Culture media from wells that contained only a $10 \mathrm{mg}$ endometrial tissue section were harvested parallel to other treatment groups and assayed for prostaglandins. The concentrations of prostaglandins were determined using commercial $\mathrm{PGF}_{2 \alpha^{\prime}} \mathrm{PGE}_{2}$ and 6-keto $\mathrm{PGF}_{1 \alpha}$ enzymeimmunoassay kits (Cayman Chemical Co., Ann Arbor, MI). The kits were used in accordance with the supplier's instructions. All samples were run in single assays and the intra-assay coefficient of variation of all assays $\leq 10 \%$.

According to the manufacturer, the $\mathrm{PGF}_{2 \alpha}$ antibody has a crossreactivity of $100 \%$ with $\mathrm{PGF}_{2 \alpha^{\prime}} \mathrm{PGF}_{1 \alpha}$ and $\mathrm{PGF}_{3 \alpha^{\prime}} 7 \%$ with $\mathrm{PGD}_{2}, 2 \%$ with 6-keto $\mathrm{PGF}_{1 \alpha^{\prime}}<0.5 \%$ with $\mathrm{PGA}_{3}, 0.3 \%$ with 2,3-dinor-6-keto $\mathrm{PGF}_{1 \alpha}$, and $<0.1 \%$ with $\mathrm{PGE}_{2}, 6,15$ diketo-13,14-dihydro $\mathrm{PGF}_{1 \alpha}$, thromboxane $\mathrm{B}_{2}$, and $\mathrm{PGE}_{3}$. The 6-keto $\mathrm{PGF}_{1 \alpha}$ antibody has a crossreactivity of $100 \%$ with 6-keto $\mathrm{PGF}_{1 \alpha^{\prime}}$ 8.7\% with 2,3-dinor-6-keto $\mathrm{PGF}_{1 \alpha^{\prime}} 2.1 \%$ with $\mathrm{PGF}_{2 \alpha^{\prime}} 0.8 \%$ with $\mathrm{PGF}_{1 \alpha^{\prime}} 0.1 \%$ with 6,15-diketo-13,14-dihydro $\mathrm{PGF}_{I \alpha^{\prime}}$ and $<0.01 \%$ with $\mathrm{PGD}_{2}, 13,14$-dihydro $\mathrm{PGF}_{I \alpha^{\prime}}$ and thromboxane $\mathrm{B}_{2}$. The $\mathrm{PGE}_{2}$ antibody has a crossreactivity of $100 \%$ with $\mathrm{PGE}_{2}$ and $\mathrm{PGE}_{3}, 9.2 \%$ with 15 -keto $\mathrm{PGE}_{2}, 0.02 \%$ with $\mathrm{PGF}_{3 \alpha^{\prime}}$ and $<0.01 \%$ with $\mathrm{PGA}_{1}, \mathrm{PGA}_{3}, \mathrm{PGB}, \mathrm{PGB}_{2}$, $\mathrm{PGD}_{2}, \mathrm{PGF}_{1 \alpha}$, 6-keto $\mathrm{PGF}_{1 \alpha}, \mathrm{PGF}_{2 \alpha^{\prime}}$ thromboxane $\mathrm{B}_{2}$ and 13,14-dihydro-15-keto $\mathrm{PGF}_{2 \alpha}$.

\section{Statistical analysis}

To reduce the variation arising from individual corpora lutea, embryos and uterine endometrium, data concerning progesterone concentrations were converted to units of stimulation index (progesterone treated/progesterone control), as described by Hickey and Hansel (1987): the progesterone control was the sample harvested $10 \mathrm{~min}$ after the treatment began (basal concentration). Progesterone stimulation index values were analysed by least squares analysis of variance using the General Linear Models procedure of SAS (SAS Institute Inc., Cary, NC). Data were analysed using the model components of corpus luteum, treatment, corpus luteum $\times$ treatment, replicate (corpus luteum $\times$ treatment), time, corpus luteum $\times$ time, treatment $\times$ time, corpus luteum $\times$ treatment $x$ time, and residual. The effect of corpus luteum and corpus luteum $\times$ treatment was tested using replicate (corpus luteum $\times$ treatment). The effect of treatment was tested using corpus luteum $\times$ treatment and the effect of time was tested using corpus luteum $\times$ time. The effect of treatment $x$ time was tested using corpus luteum $\times$ treatment $x$ time, and the remaining terms were tested with the residual. Data for prostaglandin concentrations were analysed by a one-way analysis of variance and the differences between treatment means were analysed using the Bonferroni multiple comparison test.

\section{Results}

Only very small amounts of progesterone were produced by trophoblastic vesicles, blastocyst embryos and uterine endometrial tissue alone during the $12 \mathrm{~h}$ incubation period. The concentrations $\left(\mathrm{ng} \mathrm{ml} \mathrm{ml}^{-1}\right.$ ) of progesterone (mean $\pm \mathrm{SE}$ ) in the culture medium after 2,6 and $12 \mathrm{~h}$ of incubation were $1.1 \pm 0.4,3.6 \pm 0.7$, and $3.2 \pm 1.0$, respectively, for trophoblastic vesicles, $0 \pm 0,0.2 \pm 0.2$, and $0.2 \pm 0.2$, respectively, for blastocyst-stage embryos, and $0.2 \pm 0.1,1.1 \pm 0.4$, and $1.1 \pm 0.6$, respectively, for uterine endometrial tissue. The mean concentrations (ng $\mathrm{ml}^{-1}$ ) of progesterone in the culture medium after 2,6 and $12 \mathrm{~h}$ of incubation from luteal cells alone were 51.0, 234.2 and 863.4, respectively.

After $2 \mathrm{~h}$, progesterone synthesis was stimulated by a combination of luteal cells, blastocyst-stage embryos and uterine endometrium $(P<0.10)$ (Fig. Ia). Progesterone was not stimulated by trophoblastic vesicles, blastocyst-stage embryos or endometrial tissue alone $(P>0.10)$. After $6 \mathrm{~h}$, progesterone was stimulated by trophoblastic vesicles $(P<0.01)$, blastocyststage embryos $(P<0.01)$, trophoblastic vesicles and uterine endometrium $(P<0.01)$, and blastocyst embryos and uterine endometrium $(P<0.001)$ (Fig. Ib). In addition, there was a trend for progesterone to be stimulated by treatment with a uterine endometrium sample $(P<0.10)$.

After incubation for $12 \mathrm{~h}$, trophoblastic vesicles and blastocyst-stage embryos stimulated progesterone synthesis $(P<0.001)$ (Fig. Ic). In addition, the uterine endometrium lost its stimulatory effect on progesterone synthesis and appeared to inhibit synthesis alone or in combination with trophoblastic vesicles $(P<0.10)$.

Concentrations of prostaglandins secreted into the culture medium from a uterine endometrial sample during the $12 \mathrm{~h}$ incubation period were determined and assessed for a possible correlation with progesterone data. Concentrations of $\mathrm{PGE}_{2}$, 6-keto $\mathrm{PGF}_{1 \alpha^{\prime}}$ and $\mathrm{PGF}_{2 \alpha}$ were not different $(P>0.05)$ in samples taken either after $2 \mathrm{~h}$ or $6 \mathrm{~h}$ of incubation. However, concentrations of all three compounds were significantly higher $(P<0.05)$ in the samples taken after $12 \mathrm{~h}$, compared with those taken after 2 and $6 \mathrm{~h}$ (Fig. 2).

\section{Discussion}

This study demonstrates that bovine blastocyst-stage embryos at day 7 and trophoblastic vesicles from embryos at day 12 

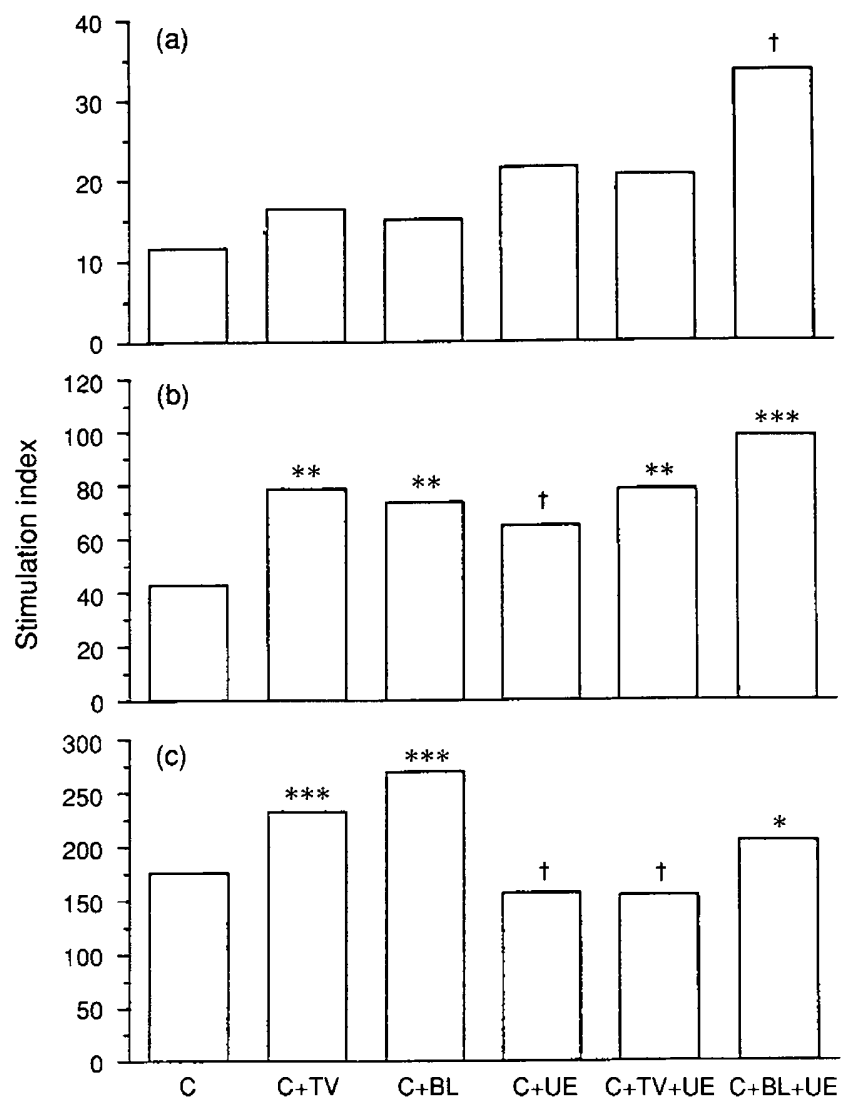

Fig. 1. Progesterone synthesis (least squares means) by bovine luteal cells (C), luteal cells with a trophoblastic vesicle $(C+T V)$, luteal cells with a blastocyst-stage embryo $(\mathrm{C}+\mathrm{BL})$, luteal cells with a uterine endometrial sample $(C+U E)$, luteal cells with a trophoblastic vesicle and uterine endometrial sample $(\mathrm{C}+\mathrm{TV}+\mathrm{UE})$, and luteal cells with a blastocyst-stage embryo and uterine endometrial sample $(\mathrm{C}+\mathrm{BL}+$ UE). Results from six corpora lutea are expressed as units of stimulation index (progesterone treated/progesterone control) from samples harvested (a) $2 \mathrm{~h}$, (b) $6 \mathrm{~h}$ and (c) $12 \mathrm{~h}$ after the treatment protocol began. The pooled SEMs of the mean is 8.0 and statistical notations are comparisons with luteal cells alone: ${ }^{\dagger} P<0.10 ;{ }^{*} P<0.05$; $* * p<0.01 ; * * *<0.001$.

produce a luteotrophic substance(s) during incubation in vitro. In addition, uterine endometrial tissue exhibits a trend to stimulate progesterone production in luteal cells after $6 \mathrm{~h}$ of incubation, although after $12 \mathrm{~h}$ it has not only lost its stimulatory capability but also inhibits the luteotrophic effects of trophoblastic vesicles. To our knowledge, this is the first report of the production of a luteotrophic substance by a single blastocyst at day 7. However, Beal et al. (1981) reported that both homogenates and aqueous extracts of homogenates of embryos at days 13-18 stimulate progesterone production by dispersed bovine luteal cells. In addition, Hickey and Hansel (1987) reported that culture medium harvested from cultured bovine conceptus tissue at days 13-18 exhibits luteotrophic activity in dispersed bovine luteal cells and showed that the luteotrophic substance has a low molecular weight, is lipid soluble, and heat labile. This same substance may have been responsible for the increased progesterone production observed in these experiments.
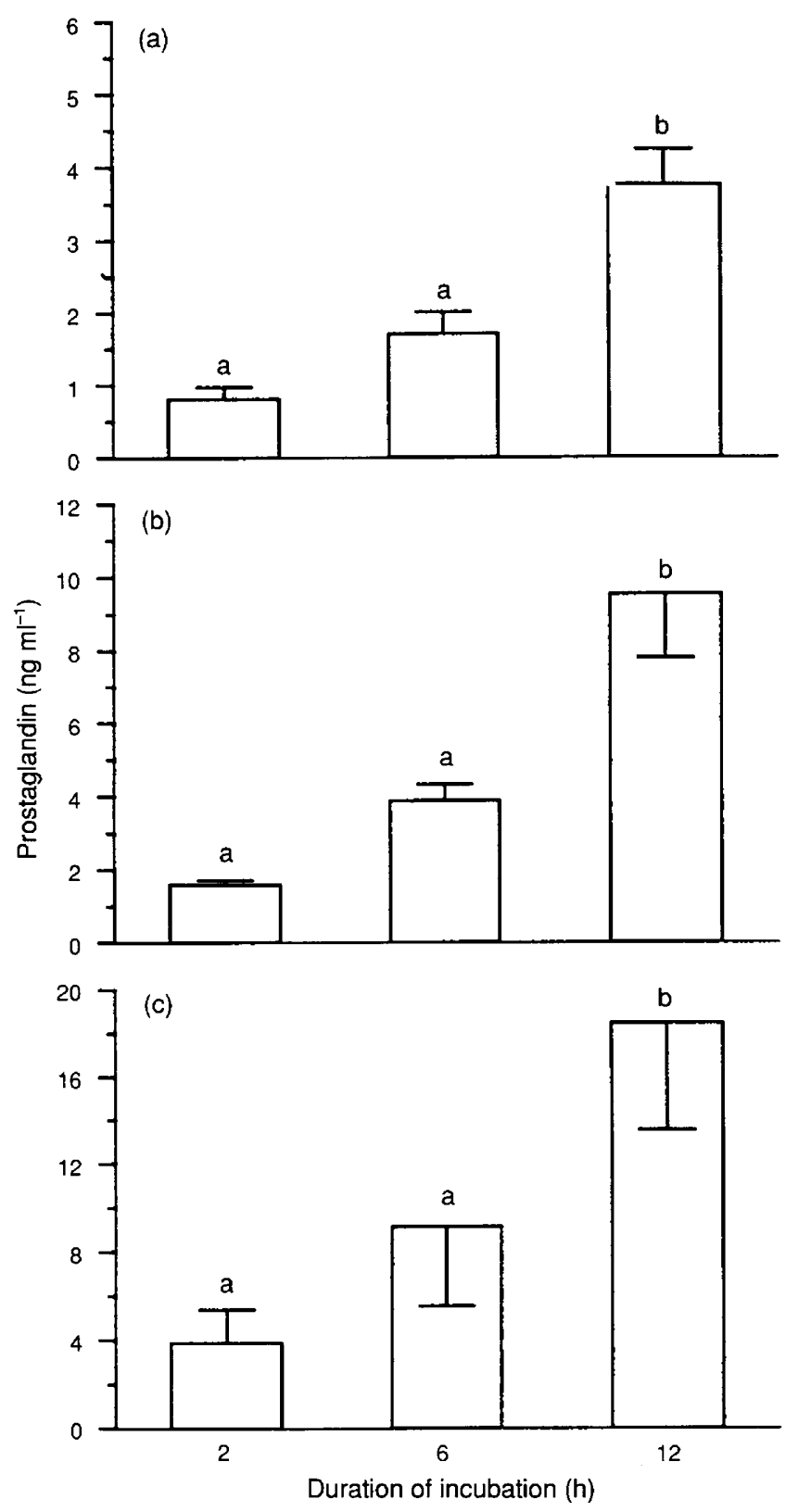

Fig. 2. Concentrations (ng $\mathrm{mi}^{-1}$ ) of the prostaglandins (a) $\mathrm{PGE}_{2}$ (b) $\mathrm{PGF}_{2 \alpha}$ and (c) 6-keto-PGF ${ }_{1 \alpha}$ secreted by bovine uterine endometrial tissue during a $12 \mathrm{~h}$ incubation period. Data are means \pm SEM from five cows using approximately $10 \mathrm{mg}$ of tissue; the experiment was replicated twice for each sampling period. Values with different letters above error bars within assays differ significantly $(P<0.05)$.

The amounts of progesterone produced directly by blastocyst-stage embryos, trophoblastic vesicles and uterine endometrium were insignificant, and the large amounts of progesterone produced in this experiment were clearly due to synthesis by the dispersed luteal cells. Wilson et al. (1992) reported that progesterone production is highly variable in bovine embryos at days 8-18 in a perifusion culture system. Bovine embryos also produce several prostanoids (Lewis et al., 1982; Shemesh et al., 1984; Hwang et al., 1988; Wilson et al., 1992) that are luteotrophic and that may be possible signals for 
the maternal recognition of pregnancy (Pratt et al., 1977; Silvia et al., 1984). In our experience, luteotrophic effects of the magnitude produced by the addition of a single blastocyst or trophoblastic vesicle to luteal cells uncontaminated with accessory cells have been produced only by $\mathrm{LH}$, or by agents that increase the concentration of cyclic AMP or that activate protein kinase $C$ (in small cells only).

Alila et al. (1988b) reported that $\mathrm{PGE}_{2}, \mathrm{PGF}_{2 \alpha}$ and $\mathrm{PGI}_{2}$ all stimulate progesterone synthesis in small bovine luteal cells, but that only $\mathrm{PGE}_{2}$ and $\mathrm{PGI}_{2}$ stimulate progesterone in large cells. Alila et al. (1988b) also reported that $\mathrm{PGF}_{2 \alpha}$ does not affect the basal concentration of progesterone in large luteal cells. In addition, the stimulation of progesterone production by $\mathrm{PGE}_{2}$ and $\mathrm{PGI}_{2}$ in the large cells is inhibited by $\mathrm{PGF}_{2 \alpha}$ (Alila et al., 1988b). However, in our experiment, the apparent switch in the effect of endometrial tissue on progesterone production in luteal cells from stimulatory to inhibitory between 6 and $12 \mathrm{~h}$ of incubation does not appear to be due to an alteration in the relative amounts of luteotrophic and luteolytic cyclooxygenase products. The concentration of all the cyclooxygenase products $\left(\mathrm{PGF}_{2 \alpha}, \mathrm{PGE}_{2}\right.$ and $\left.\mathrm{PGI}_{2}\right)$ increased over time. The ratios of $\mathrm{PGE}_{2}: \mathrm{PGF}_{2 \alpha}$ and of 6-keto-PGF $1 \alpha: \mathrm{PGF}_{2 \alpha}$ after 2,6 and $12 \mathrm{~h}$ of incubation were $0.51: 1$ and 2.45:1, 0.44:1 and $2.36: 1$, and $0.39: 1$ and 1.94:1, respectively. It seems more likely that these results could be attributed to an increased production of lipoxygenase products over time; these products are known to have luteolytic properties (Milvae et al., 1986). However, the attenuation of the inhibitory effects of uterine endometrium on progesterone production when co-incubated with a trophoblastic vesicle or blastocyst-stage embryo could be due to a shift in the metabolism of arachidonic acid toward $\mathrm{PGE}_{2}$ synthesis rather than $\mathrm{PGF}_{2 \alpha^{\prime}}$ as described by Lewis and Waterman (1983). The inhibitory effects of the uterine endometrium could also be due to the metabolism of progesterone in the culture medium (Eley et al., 1983).

These data indicate that early-stage bovine embryos produce a factor(s) that can stimulate progesterone production in luteal cells several days before the generally accepted period of maternal recognition of pregnancy. This factor can act directly on luteal cells to stimulate progesterone production. The endometrium also produces both luteotrophic and luteolytic arachidonic acid metabolites, but these do not appear to enhance the luteotrophic effects of the early embryo and may even inhibit them under certain circumstances.

This manuscript was approved for publication by the Director of the Louisiana Agricultural Experiment Station as manuscript number 93-11-7310. The authors thank G. S. Lewis for his helpful advice during the course of this study and B. Stroud (Stroud Veterinary Embryo Services, Inc., Weatherford, TX) for providing the bovine embryos.

\section{References}

Alila HW, Dowd JP, Corradino RA, Harris WV and Hansel W (1988a) Control of progesterone production in small and large bovine luteal cells separated by flow cytometry Journal of Reproduction and Fertility 82 645-655

Alila HW, Corradino RA and Hansel W (1988b) A comparison of the effects of cyclooxygenase prostanoids on progesterone production by small and large bovine luteal cells Prostaglandins 36 259-270
Battista PJ, Alila HW, Rexroad CE, Jr and Hansel W (1989) The effects of platelet-activating factor and platelet-derived compounds on bovine luteal cell progesterone production Biology of Reproduction 40 769-775

Beal WE, Lukaszewska JH and Hansel W (1981) Luteotropic effects of bovine blastocysts Joumal of Animal Science 52 567-574

Betteridge KJ, Eaglesome MD, Randall GCB and Mitchell D (1980) Collection, description and transfer of embryos from cattle 10-10 days after oestrus Journal of Reproduction and Fertility 59 205-216

Del Vecchio RP, Thibodeaux JK, Randel RD and Hansel W (1994) Interactions between large and small bovine luteal cells in a sequential perifusion co-culture system Journal of Animal Science 72 963-968

Eley RM, Thatcher WW, Bazer FW and Fields MJ (1983) Steroid metabolism by the bovine uterine endometrium and conceptus Biology of Reproduction 28 804-816

Helmer SD, Hansen PJ, Thatcher WW, Johnson JW and Bazer FW (1989a) Intrauterine infusion of highly enriched bovine trophoblast protein- 1 complex exerts an antiluteolytic effect to extend corpus luteum lifespan in cyclic cattle Journal of Reproduction and Fertility 87 89-101

Helmer SD, Gross TS, Newton GR, Hansen PJ and Thatcher WW (1989b) Bovine trophoblast protein-I complex alters endometrial protein and prostaglandin secretion and induces an intracellular inhibitor of prostaglandin synthesis in vitro Journal of Reproduction and Fertility 87 421-430

Hernandez-Ledezma JJ, Sikes JD, Murphy CN, Watson AJ, Schultz GA and Roberts RM (1992) Expression of bovine trophoblast interferon in conceptuses derived by in vitro techniques Biology of Reproduction 47 374-380

Hickey GJ and Hansel W (1987) In-vitro synthesis of a low molecular weight lipid-soluble luteotropic factor by conceptuses of cows at days 13-18 of pregnancy Journal of Reproduction and Fertility 80 569-576

Hwang DH, Pool SH, Rorie RW, Boudreau M and Godke RA (1988) Transitional changes in arachidonic acid metabolism by bovine embryos at different developmental stages Prostaglandins 35 387-402

Koos RD and Hansel W (1981) The large and small cells of the bovine corpus luteum: ultrastructure and functional differences. In Dynamics of Ovarian Finction pp 197-203 Eds NB Schwartz and M Hunzicker-Dunn. Raven Press, New York

Lamming GE, Darwash AO and Black HL (1989) Corpus luteum function in dairy cows and embryo mortality Journal of Reproduction and Fertility Supplement 37 245-252

Lewis GS (1989) Prostaglandin secretion by the blastocyst Journal of Reproduction and Fertility Supplement 37 261-267

Lewis GS and Waterman RA (1983) Effects of endometrium on metabolism of arachidonic acid by bovine blastocysts in vitro Prostaglandins 25 881-889

Lewis GS, Thatcher WW, Bazer FW and Curl JS (1982) Metabolism of arachidonic acid in vitro by bovine blastocysts and endometrium Biology of Reproduction 27 431-439

Lukaszewska J and Hansel $W$ (1980) Corpus luteum maintenance during early pregnancy in the cow Joumal of Reproduction and Fertility 59 485-493

Milvae RA, Alila HW and Hansel W (1986) Involvement of lipoxygenase products of arachidonic acid metabolism in bovine luteal function Biology of Reproduction 35 1210-1215

Northey DL and French LR (1980) Effect of embryo removal and intrauterine infusion of embryonic homogenates on the lifespan of the corpus luteum Journal of Animal Science $\mathbf{5 0}$ 298-302

Pool SH, Rorie RW, Pendleton RJ, Menino AR and Godke RA (1988) Culture of early-stage bovine embryos inside day- 13 and day-14 precultured trophoblastic vesicles Annals of the New York Academy of Science 541 407-418

Pratt BR, Butcher RL and Inskeep EK (1977) Antiluteolytic effect of the conceptus and of prostaglandin E-2 in ewes Journal of Animal Science 46 784-791

Shemesh M, Mileguir F, Ayalon N and Hansel W (1979) Steroidogenesis and prostaglandin synthesis by cultured bovine blastocysts Joumal of Reproduction and Fertility 56 181-185

Shemesh M, Hansel W, Strauss J, III, Raefaeli A, Lavi S and Mileguir F (1984) Control of prostanoid synthesis in bovine trophoblast and placentome Animal Reproduction Science 7 177-194

Silvia WJ, Fitz RA, Mayan MH and Niswender GD (1984) Cellular and molecular mechanisms involved in luteolysis and maternal recognition of pregnancy in the ewe Animal Reproduction Science 7 57-74

Stock AE and Hansel W (1992) Assay of embryo-derived platelet activating factor (EDPAF) by an equine platelet aggregation assay: preliminary data concerning its presence in bovine embryo culture media Theriogenology 38 757-768 
Thatcher WW, Knickerbocker JJ, Helmer SD, Hansen PJ, Bartol FF, Bazer FW and Roberts RM (1985) Characterization of conceptus secretory proteins and their effects on $\mathrm{PGF}_{2 \alpha}$ secretion by maternal endometrium in cattle. In Early Pregnancy Factors pp 25-28 Eds F Ellendorf and E Koch. Perinatology Press, Ithaca

Thatcher WW, Hansen PJ, Gross TS, Helmer SD, Plante C and Bazer FW (1989) Antiluteolytic effects of bovine trophoblast protein-1 journal of Reproduction and Fertility Supplement 37 91-99

Thibodeaux JK, Menezo Y, Roussel JD, Hansel W, Goodeaux LL, Thompson DL, Jr and Godke RA (1992) Coculture of in vitro fertilized bovine embryos with oviductal epithelial cells originating from different stages of the estrous cycle Journal of Dairy Science 75 1448-1455
Thibodeaux JK, Del Vecchio RP and Hansel W (1993) The role of plateletderived growth factor in development of in vitro matured and in vitro fertilized bovine embryos Journal of Reproduction and Fertility 98 61-66

Watson AJ, Hogan A, Hahnel A, Wiemer KE and Schultz GA (1992) Expression of growth factor ligand and receptor genes in the preimplantation bovine embryo Molecular Reproduction and Development 31 87-95

Wilson JM, Zalesky DD, Looney CR, Bondioli KR and Magness RR (1992) Hormone secretion by preimplantation embryos in a dynamic in vitro culture system Biology of Reproduction 46 295-300 